\title{
Pemodelan Penjualan Produk Herbal Menggunakan Metode Monte Carlo
}

\author{
${ }^{1}$ Elvin Syahrin, ${ }^{2}$ Julius Santony, ${ }^{3}$ Jufriadif Na'am \\ ${ }^{1}$ Fakultas Ilmu Komputer Universitas Potensi Utama \\ ${ }^{2,3}$ Fakultas Ilmu Komputer, Universitas Putra Indonesia YPTK \\ e-mail: ${ }^{1}$ elvinsyahrinchan@ymail.com, ${ }^{2}$ juliussantony@yahoo.co.id, ${ }^{3}$ jufriadifnaam@gmail.com
}

\begin{abstract}
Sales are a source of life for a company. Predicting the number of sales is important in analyzing the development of sales. Analysis of sales development is an important factor in increasing sales. Using the Monte Carlo method can predict the accuracy of the data items in the company. The results of this study on data processing in 2016 until 2017 have an accuracy of 97\%. So this research is very precise in predicting sales for the future.
\end{abstract}

Keywords: Monte Carlo, Modeling, Simulation, Sales, Herbs

\begin{abstract}
Abstrak
Penjualan merupakan sumber hidup suatu perusahaan. Memprediksi jumlah penjualan merupakan hal penting dalam menganalisis perkembangan penjualan. Analisis perkembangan penjualan ini merupakan faktor penting dalam meningkatkan penjualan. Dengan menggunakan metode Monte Carlo dapat memprediksi ketepatan terhadap data barang pada perusahaan. Hasil penelitian ini terhadap pengolahan data tahun 2016 hingga tahun 2017 memiliki akurasi 97\%. Sehingga penelitian ini sangat tepat dalam memprediksi penjualan untuk masa yang akan datang.
\end{abstract}

Kata kunci:Monte Carlo, Pemodelan, Simulasi, Penjualan, Herbal

\section{Pendahuluan}

Penjualan merupakan suatu kegiatan atau usaha konkrit yang dilakukan untuk memindahkan suatu produk dari produsen kepada konsumen demi mendatangkan keuntungan atau laba dari produk ataupun barang yang dihasilkan produsennya dengan pengelolaan yang baik [1].

Permintaan pasar yang tidak menentu membuat suatu pelaku usaha belum mampu sepenuhnya memperkirakan seberapa banyak barang yang harus disediakan berdasarkan permintaan pasar. Mempredikisikan penjualan adalah kegiatan untuk mengestimasi besarnya penjualan barang atau jasa oleh produsen, distributor pada periode waktu dan wilayah pemasaran tertentu. Salah satu kontribusi keberhasilan suatu perusahaan dengan memprediksikan penjualan merupakan bagian fungsi manajemen. Ketika penjualan diprediksi dengan akurat maka pemenuhan permintaan konsumen dapat diusahakan tepat waktu, kerjasama perusahaan dengan relasi tetap terjaga dengan baik, kepuasan konsumen terpenuhi, perusahaan dapat mengatasi hilangnya penjualan atau kehabisan stok, mencegah pelanggan lari ke kompetitor. Perencanaan kuantitas produksi yang tepat pelaku usaha akan dapat memprediksi dengan baik kemungkinan keuntungan yang diperoleh di waktu mendatang. Hal ini dianggap penting karena dapat dijadikan sebagai acuan bagi pelaku usaha untuk mengevaluasi usahanya. Namun untuk mengetahui perkembangan penjualan tersebut 
perlu adanya sistem yang sistematis dalam memprediksi permintaan pasar. Untuk dapat memprediksi penjualan tersebut maka dibutuhkan data-data penjualan sebelumnya [2].

Model merupakan sebagai representasi dari sistem baik secara kualitatif yang mewakili suatu proses atau kejadian, dimana dapat menggambarkan secara jelas hubungan interaksi antar berbagai faktor-faktor penting yang akan diamati [3]. Pada umumnya model didefinisikan sebagai suatu representasi sistem nyata. Sistem nyata adalah sistem yang sedang berlangsung di dunia nyata dan menjadi permasalahan yang sedang diteliti.

Simulasi Monte Carlo merupakan suatu metode yang digunakan untuk mengevaluasi suatu model deterministik yang melibatkan bilangan acak sebagai salah satu input. Bilangan acak yang digunakan yaitu bilangan acak berdistribusi normal baku. Tujuan simulasi adalah pelatihan (training), studi perilaku sistem (behaviour), hiburan atau permainan (game). Pada prinsipnya, simulasi sama seperti menjalankan tes lapangan, bahwa sistem yang diminati digantikan oleh model terkomputerisasi. Simulasi melibatkan pembuatan model yang meniru perilaku yang menarik dengan model untuk menghasilkan pengamatan perilaku sistem [4].

Dikatakan juga simulasi merupakan suatu proses perancangan model dari suatu sistem nyata yang bertujuan untuk memahami tingkah laku atau untuk menyusun strategi sehubungan dengan beroperasinya sistem tersebut. Ide dasar simulasi adalah dengan membangun alat peraga sebagai percobaan yang hampir menyerupai (simulator) dari sistem dalam mempelajari respon tiap-tiap variabel dalam waktu yang lebih cepat, dan dengan biaya yang lebih murah. Monte Carlo adalah suatu metode untuk mengevaluasi secara berulang suatu model deterministik menggunakan himpunan bilangan acak sebagai masukan. Metode ini sering digunakan bila model adalah kompleks, non linier, atau melibatkan banyak parameter tertentu yang saling berhubungan [5].

Metode Monte Carlo adalah "kelas luas algoritma komputasi yang pada pengambilan sampel acak berulang untuk mendapatkan hasil numerik". Pada prinsipnya, pendekatan ini dapat digunakan untuk menyelesaikan masalah komputasi yang melibatkan variabel acak. Ketika metode Monte Carlo digunakan dalam program untuk memperkirakan indikator kinerja tertentu dari sistem dunia nyata [6]. Metode Monte Carlo dapat menganalisis, memecahkan dan mengoptimalkan berbagai masalah matematika atau fisik melalui sejumlah besar sampel acak statistik untuk simulasi kejadian stokastik. [7]

Metode Monte Carlo dibagi menjadi dua yaitu Monte Carlo Standard dan Monte Carlo Variance Reduction. Metode Monte Carlo Standar adalah sebuah teknik untuk menyelesaikan suatu masalah dengan menjalankan percobaan dalam jumlah banyak, yang disebut simulasi, untuk mendapatkan hasil yang paling mendekati dari percobaan yang dilakukan. [8]

Pembangunan model simulasi monte carloberdasarkan pada probabilitas yang diperoleh dari data historis dari sebuah kejadian dan frekuensinya[9]. Simulasi Monte Carlo adalah suatu metode untuk mengevaluasi secara berulang suatu model deterministik menggunakan himpunan bilangan acak sebagai masukan. Metode Monte Carlo banyak digunakan di berbagai disiplin ilmu, dari simulasi eksperimen, melalui penghitungan jenis integral tertentu, untuk, misalnya menyelesaikan persamaan diferensial. Ini merupakan metode stokastik menggunakan pembangkit bilangan acak. Ide dasar dari metode ini sangat sederhana [10].

Model simulasi yang dibangun harus kredibel. Representasi kredibel sistem nyata oleh model simulasi ditunjukkan oleh validasi model. Validasi model adalah proses pemeriksaan untuk mengetahui suatu data (model dan sistem nyata) valid atau tidak. Model dikatakan valid apabila 
hasil perbandingan menunjukkan bahwa kedua alternatif (model dan real system) tidak berbeda secara signifikan [11].

Keuntungan yang diperoleh dengan memanfaatkan simulasi adalah menghemat waktu, dapat mengawasi sumber-sumber yang bervariasi jika berkaitan dengan hubungan beberapa variabel yang diteliti, bahkan harus menguraikan sejumlah input dari beberapa sumber yang bervariasi., mengkoreksi kesalahan- kesalahan perhitungan jika diambil angka-angka yang teratur dan bebas serta percobaan komputer dapat dilakukan setiap saat dan dapat diulang-ulang [12].

\section{Data dan Metode Penelitian}

Data yang digunakan dalam penelitian ini adalah data historis selama dua tahun yaitu data tahun 2016 dan tahun 2017. Menyelesaikan suatu sistem perlu dilakukan pengumpulan data secara bertahap. Berdasarkan studi pustaka yang ada dan observasi secara langsung, maka data disusun dan dikelompokkan dalam bentuk tabel multikriteria sederhana. Hal ini dilakukan agar mempermudah dalam melakukan analisa data.

\subsection{Kerangka Penelitian}

Susunan kerangka kerja harus memiliki tahapan-tahapan yang sistematis yang dapat membantu dalam menyelesaikan penelitian yang berkaitan dengan metode Monte Carlo. Adapun kerangka kerja penelitian yang digunakan seperti terlihat pada gambar 1 .

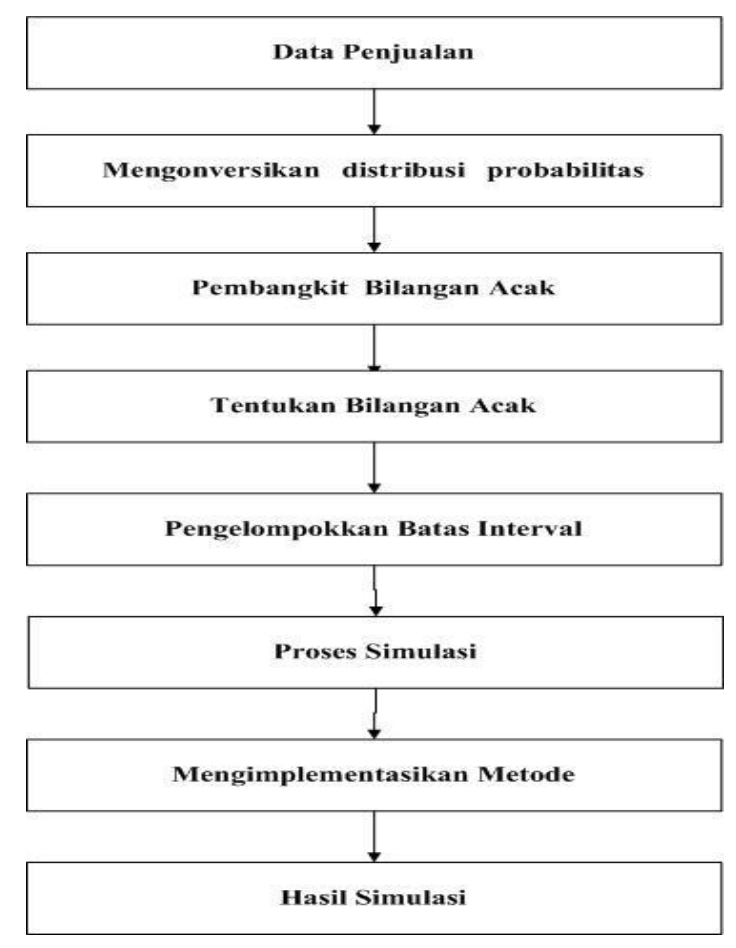

Gambar 1:Kerangka Kerja Penelitian

Keterangan :

1. Data Penjualan

Penganalisaan data yang diambil dari data penjualan, dimana data sudah diperoleh dari tahap proses pengumpulan data, data disusun, dan digolongkan kedalam susunan tabel yang mudah 
untuk dipahami oleh semua pihak. Data penjualan yang digunakan dipastikan data yang jelas, akurat dan sesuai dengan kebutuhan dalam penelitian.

2. Mengonversikan distribusi probabilitas

Mengonversikan distribusi probabilitas ke dalam bentuk frekuensi kumulatif.

3. Pembangkit Bilangan Acak

Bilangan acak dikategorikan sesuai dengan rentang distribusi probabilitas kumulatif dari variabel-variabel yang di gunakan dalam simulasi.

4. Tentukan Bilangan Acak

Penentuan bialangan acak diantaranya yaitu Table Random Number, tabel ini sudah banyak ditemukan mulai dari enam digit sampai dengan belasan digit, Electronic Random Number, number ini banyak juga dipergunakan dalam percobaan penelitian, dan Conguential Pseudo Random Number Generator.

5. Pengelompokkan Batas Interval

Distribusi probabilitas kumulatif ini akan digunakan sebagai dasar pengelompokan batas interval dari bilangan acak.

6. Proses Simulasi

Proses simulasi menggunakan data penjualan dipastikan data yang jelas, akurat dan sesuai dengan kebutuhan.

7. Mengimplementasikan dengan Monte Carlo

Mekanisme pengujian untuk membandingkan hasil yang didapatkan dengan proses perhitungan Monte Carlo untuk menentukan simulasi jumlah penjualan pertahun dengan hasil yang didapatkan dengan menggunakan simulasi yang telah dirancang.

8. Hasil Simulasi

Hasil simulasi akan dapat dilihat apakah simulasi monte carlo dapat memenuhi harapan dalam memprediksi penjualan yang sesuai dengan target perusahaan sehingga dapat dijadikan keputusan dalam mengambil kebijakan, dan perangkat lunak yang digunakan adalah Matlab 2014a.

\section{Hasil dan Diskusi}

Data yang digunakan adalah data rekapitulasi jumlah penjualan produk herbal dalam kurun waktu satu tahun. Untuk penyelesaiannya menggunakan metode monte carlo dalam menentukan penjualan tahun berikutnya.

Tabel 1 : Rekapitulasi Jumlah Penjualan Produk Herbal Tahun 2016

\begin{tabular}{|c|c|c|c|c|c|c|c|c|c|c|c|c|c|c|c|}
\hline \multirow{2}{*}{ No } & \multirow{2}{*}{ Kode } & \multirow{2}{*}{ Nama Barang } & \multicolumn{12}{|c|}{ Jumlah Penjualan Tahun 2016} & \multirow{2}{*}{ Total } \\
\hline & & & Jan & Feb & Mar & Apr & Mei & Jun & Jul & Ags & Sep & Okt & Nov & Des & \\
\hline 1 & E1 & Balqis Sabun Susu Jasmine & 3 & 3 & 2 & 4 & 3 & 3 & 3 & 2 & 3 & 2 & 1 & 2 & 31 \\
\hline 2 & E2 & Balqis Sabun Susu Lemon & 3 & 3 & 2 & 4 & 2 & 2 & 2 & 3 & 3 & 3 & 3 & 3 & 33 \\
\hline \multicolumn{15}{|c|}{ Total Keseluruhan } & 107 \\
\hline
\end{tabular}

Tabel 2 : Rekapitulasi Jumlah Penjualan Produk Herbal Tahun 2017

\begin{tabular}{|c|c|c|c|c|c|c|c|c|c|c|c|c|c|c|c|}
\hline \multirow[t]{2}{*}{ No } & \multirow{2}{*}{ Kode } & \multirow{2}{*}{ Nama Barang } & \multicolumn{12}{|c|}{ Jumlah Penjualan Tahun 2017} & \multirow{2}{*}{ Total } \\
\hline & & & Jan & Feb & Mar & Apr & Mei & Jun & Jul & Ags & Sep & Okt & Nov & Des & \\
\hline 1 & E1 & Balqis Sabun Susu Jasmine & 3 & 4 & 3 & 2 & 3 & 4 & 2 & 3 & 5 & 2 & 2 & 2 & 35 \\
\hline 2 & E2 & Balqis Sabun Susu Lemon & 2 & 3 & 3 & 2 & 1 & 5 & 3 & 2 & 2 & 6 & 2 & 2 & 33 \\
\hline \multicolumn{15}{|c|}{ Total Keseluruhan } & 114 \\
\hline
\end{tabular}

Tahapan penyelesaian simulasi monte carlo sebagai berikut :

1. Membuat Distribusi Probabilitas dari Variabel.

Untuk menentukan ditribusi probabilitas dapat diperoleh dengan rumus :

Distribusi Probabilitas $\quad K e-i=\frac{\text { Jumlah Penjualan Ke-i }}{\text { Total Penjualan }(n)}$ 
Perhitungan distribusi probabilitas E1, E2, sampai E33 masing-masing jumlah penjualan ke-i dibagi total penjualan ke-n sehingga nilai total penjualan yang dihasilkan jika benar

\begin{tabular}{|c|c|c|c|c|c|c|c|c|c|c|c|c|c|c|}
\hline Kode & Bulan & 1 & 2 & 3 & 4 & 5 & 6 & 7 & 8 & 9 & 10 & 11 & 12 & Total \\
\hline \multirow[t]{2}{*}{ E1 } & Jumlah & 3 & 3 & 2 & 4 & 3 & 3 & 3 & 2 & 3 & 2 & 1 & 2 & 31 \\
\hline & Probabilitas & 0.097 & 0.097 & 0.065 & 0.129 & 0.097 & 0.097 & 0.097 & 0.065 & 0.097 & 0.065 & 0.032 & 0.065 & 1.000 \\
\hline \multirow[t]{2}{*}{ E2 } & Jumlah & 3 & 3 & 2 & 4 & 2 & 2 & 2 & 3 & 3 & 3 & 3 & 3 & 33 \\
\hline & Probabilitas & 0.091 & 0.091 & 0.061 & 0.121 & 0.061 & 0.061 & 0.061 & 0.091 & 0.091 & 0.091 & 0.091 & 0.091 & 1.000 \\
\hline \multirow[t]{2}{*}{ E3 } & Jumlah & 5 & 3 & 5 & 3 & 3 & 3 & 3 & 4 & 3 & 3 & 4 & 4 & 43 \\
\hline & Probabilitas & 0.116 & 0.070 & 1 & 0.070 & 0.070 & 0.070 & 0.070 & 0.093 & 0.070 & 0.070 & 0.093 & 0.093 & 1.884 \\
\hline
\end{tabular}

perhitungan probabilitasnya yaitu angka 1 .

\begin{tabular}{|c|c|c|c|c|c|c|c|c|c|c|c|c|c|c|}
\hline Kode & Bulan & 1 & 2 & 3 & 4 & 5 & 6 & 7 & 8 & 9 & 10 & 11 & 12 & Total \\
\hline \multirow[t]{2}{*}{ E1 } & Jumlah & 3 & 4 & 3 & 2 & 3 & 4 & 2 & 3 & 5 & 2 & 2 & 2 & 35 \\
\hline & Probabilitas & 0.086 & 0.114 & 0.086 & 0.057 & 0.086 & 0.114 & 0.057 & 0.086 & 0.143 & 0.057 & 0.057 & 0.057 & 1.000 \\
\hline \multirow[t]{2}{*}{ E2 } & Jumlah & 2 & 3 & 3 & 2 & 1 & 5 & 3 & 2 & 2 & 6 & 2 & 2 & 33 \\
\hline & Probabilitas & 0.061 & 0.091 & 0.091 & 0.061 & 0.030 & 0.152 & 0.091 & 0.061 & 0.061 & 0.182 & 0.061 & 0.061 & 1.000 \\
\hline \multirow[t]{2}{*}{ E3 } & Jumlah & 3 & 4 & 3 & 4 & 4 & 4 & 4 & 3 & 4 & 4 & 5 & 4 & 46 \\
\hline & Probabilitas & 0.065 & 0.087 & 0.065 & 0.087 & 0.087 & 0.087 & 0.087 & 0.065 & 0.087 & 0.087 & 0.109 & 0.087 & 1.000 \\
\hline
\end{tabular}

Tabel 3 : Distribusi Probabilitas Penjualan Produk Herbal Tahun 2016

Tabel 4 : Distribusi Probabilitas Penjualan Produk Herbal Tahun 2017

2. Menghitung Distribusi Kumulatif Dari Variabel Distribusi Probabilitas.

Perhitungan distribusi kumulatif dengan cara menjumlahkan setiap angka kemungkinan dengan jumlah sebelumnya yaitu untuk tipe E1, E2 dan seterusnya. Untuk masing-masing produk herbal tersebut dilakukan proses perhitungan E1 bulan ke-1 Probabilitas ke-1 menghasilkan angka sama yaitu Distribusi Kumulatif ke-1 dan selanjutnya dari distribusi kumulatif dijumlahkan dengan distribusi probabilitas yang sebelumnya sehinggah total ke-nnya adalah 1,000 ditetapkan 3 digit di belakang koma.

Tabel 5 : Kemungkinan Kumulatif Penjualan Produk Herbal Tahun 2016

\begin{tabular}{|c|c|c|c|c|c|c|c|c|c|c|c|c|c|c|}
\hline Kode & Bulan & 1 & 2 & 3 & 4 & 5 & 6 & 7 & 8 & 9 & 10 & 11 & 12 & Total \\
\hline \multirow[t]{3}{*}{ E1 } & Jumlah & 3 & 3 & 2 & 4 & 3 & 3 & 3 & 2 & 3 & 2 & 1 & 2 & 31 \\
\hline & Probabilitas & 0.097 & 0.097 & 0.065 & 0.129 & 0.097 & 0.097 & 0.097 & 0.065 & 0.097 & 0.065 & 0.032 & 0.065 & 1.000 \\
\hline & Kumulatif & 0.097 & 0.194 & 0.258 & 0.387 & 0.484 & 0.581 & 0.677 & 0.742 & 0.839 & 0.903 & 0.935 & 1.000 & \\
\hline \multirow[t]{3}{*}{ E2 } & Jumlah & 3 & 3 & 2 & 4 & 2 & 2 & 2 & 3 & 3 & 3 & 3 & 3 & 33 \\
\hline & Probabilitas & 0.091 & 0.091 & 0.061 & 0.121 & 0.061 & 0.061 & 0.061 & 0.091 & 0.091 & 0.091 & 0.091 & 0.091 & 1.000 \\
\hline & Kumulatif & 0.091 & 0.182 & 0.242 & 0.364 & 0.424 & 0.485 & 0.545 & 0.636 & 0.727 & 0.818 & 0.909 & 1.000 & \\
\hline \multirow[t]{3}{*}{ E3 } & Jumlah & 5 & 3 & 5 & 3 & 3 & 3 & 3 & 4 & 3 & 3 & 4 & 4 & 43 \\
\hline & Probabilitas & 0.116 & 0.070 & 1.000 & 0.070 & 0.070 & 0.070 & 0.070 & 0.093 & 0.070 & 0.070 & 0.093 & 0.093 & 1.884 \\
\hline & Kumulatif & 0.116 & 0.186 & 1.186 & 1.256 & 1.326 & 1.395 & 1.465 & 1.558 & 1.628 & 1.698 & 1.791 & 1.884 & \\
\hline
\end{tabular}

Tabel 6 : Kemungkinan Kumulatif Penjualan Produk Herbal Tahun 2017

\begin{tabular}{|c|c|c|c|c|c|c|c|c|c|c|c|c|c|c|}
\hline Kode & Bulan & 1 & 2 & 3 & 4 & 5 & 6 & 7 & 8 & 9 & 10 & 11 & 12 & Total \\
\hline \multirow[t]{3}{*}{ E1 } & Jumlah & 3 & 3 & 2 & 4 & 3 & 3 & 3 & 2 & 3 & 2 & 1 & 2 & 31 \\
\hline & Probabilitas & 0.097 & 0.097 & 0.065 & 0.129 & 0.097 & 0.097 & 0.097 & 0.065 & 0.097 & 0.065 & 0.032 & 0.065 & 1.000 \\
\hline & Kumulatif & 0.097 & 0.194 & 0.258 & 0.387 & 0.484 & 0.581 & 0.677 & 0.742 & 0.839 & 0.903 & 0.935 & 1.000 & \\
\hline \multirow[t]{3}{*}{ E2 } & Jumlah & 3 & 3 & 2 & 4 & 2 & 2 & 2 & 3 & 3 & 3 & 3 & 3 & 33 \\
\hline & Probabilitas & 0.091 & 0.091 & 0.061 & 0.121 & 0.061 & 0.061 & 0.061 & 0.091 & 0.091 & 0.091 & 0.091 & 0.091 & 1.000 \\
\hline & Kumulatif & 0.091 & 0.182 & 0.242 & 0.364 & 0.424 & 0.485 & 0.545 & 0.636 & 0.727 & 0.818 & 0.909 & 1.000 & \\
\hline \multirow[t]{3}{*}{ E3 } & Jumlah & 5 & 3 & 5 & 3 & 3 & 3 & 3 & 4 & 3 & 3 & 4 & 4 & 43 \\
\hline & Probabilitas & 0.116 & 0.070 & 1.000 & 0.070 & 0.070 & 0.070 & 0.070 & 0.093 & 0.070 & 0.070 & 0.093 & 0.093 & 1.884 \\
\hline & Kumulatif & 0.116 & 0.186 & 1.186 & 1.256 & 1.326 & 1.395 & 1.465 & 1.558 & 1.628 & 1.698 & 1.791 & 1.884 & \\
\hline
\end{tabular}

3. Membuat Interval Dari Masing-Masing Variabel

Bilangan acak yang digunakan adalah bilangan acak 3 digit dikarenakan nilai distribusi probabilitas penjualan dan probabilitas kumulatif memiliki 3 digit belakang koma. Adapun interval bilangan acak E1, E2 dan seterusnya didapat dari proses perhitungan algoritma Monte 
Carlo distribusi probabilitas dan distribusi kumulatif yaitu E1, ke-i=000 sampai dengan probabilitas kumulatif ke-i dikurang 1 . Setelah itu hasil ke-i dikurang 1 dijadikan untuk perhitungan berikutnya hingga didapatkan angka 999 seperti gambar 2 dan gambar 3.

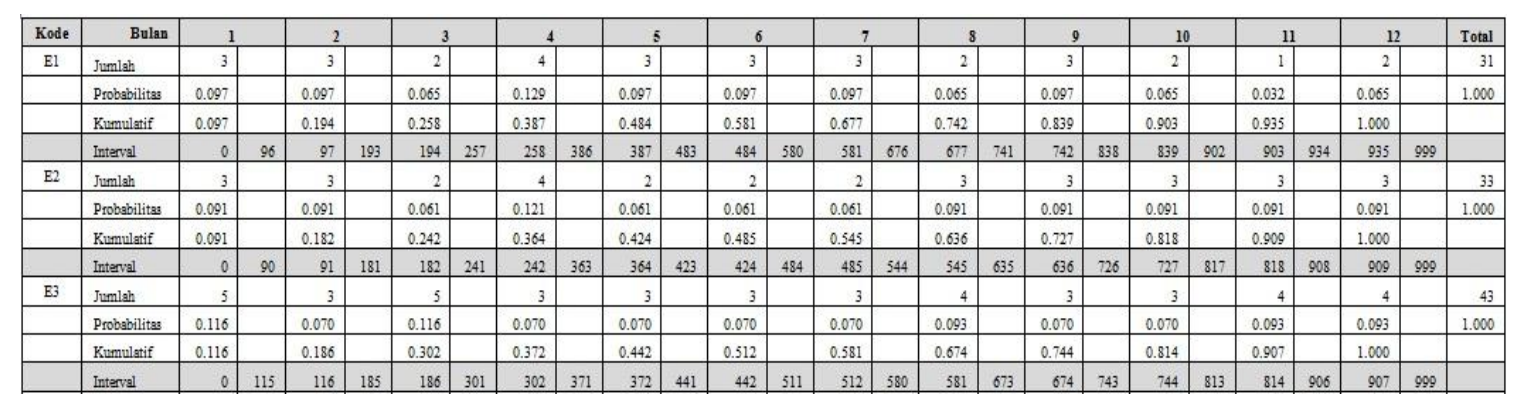

Gambar 2: Interval Variabel Tahun 2016

\begin{tabular}{|c|c|c|c|c|c|c|c|c|c|c|c|c|c|c|c|c|c|c|c|c|c|c|c|c|c|c|}
\hline Kode & Bulan & \multicolumn{2}{|l|}{1} & \multicolumn{2}{|l|}{2} & \multicolumn{2}{|c|}{3} & \multicolumn{2}{|c|}{4} & \multicolumn{2}{|l|}{5} & \multicolumn{2}{|l|}{6} & \multicolumn{2}{|c|}{7} & \multicolumn{2}{|c|}{8} & \multicolumn{2}{|l|}{9} & \multicolumn{2}{|c|}{10} & \multicolumn{2}{|l|}{11} & \multicolumn{2}{|l|}{12} & \multirow{2}{*}{\begin{tabular}{|r|} 
Total \\
35
\end{tabular}} \\
\hline \multirow[t]{4}{*}{ E1 } & \begin{tabular}{|l|} 
Jumlah \\
\end{tabular} & 3 & & 4 & & 3 & & 2 & & 3 & & 4 & & 2 & & 3 & & 5 & & 2 & & 2 & & 2 & & \\
\hline & Probabilitas & 0.086 & & 0.114 & & 0.086 & & 0.057 & & 0.086 & & 0.114 & & 0.057 & & 0.066 & & 0.143 & & 0.057 & & $\begin{array}{ll}0.057 \\
\end{array}$ & & 0.057 & & 1.000 \\
\hline & Kumulatif & 0.086 & & 0.200 & & 0.286 & & 0.343 & & 0.429 & & 0.543 & & 0.600 & & 0.686 & & 0.829 & & 0.886 & & \begin{tabular}{l|l|}
0.943 \\
\end{tabular} & & 1.000 & & \\
\hline & \begin{tabular}{|l|} 
Interval \\
\end{tabular} & 0 & 85 & 86 & 199 & 200 & 285 & 286 & 342 & 343 & 428 & 429 & 542 & 543 & 599 & 600 & 685 & 666 & 828 & 829 & 885 & 886 & 942 & 943 & 999 & \\
\hline E2 & Jutulah & 2 & & 3 & & 3 & & 2 & & 1 & & 5 & & 3 & & 2 & & 2 & & 5 & & 2 & & 2 & & 33 \\
\hline & Probabilitas & 0.061 & & 0.091 & & 0.091 & & 0.061 & & 0.030 & & 0.152 & & 0.091 & & 0.061 & & 0.061 & & 0.182 & & 0.061 & & 0.061 & & 1.000 \\
\hline & Kumulatif & 0.061 & & 0.152 & & 0.242 & & 0.303 & & 0.333 & & 0.485 & & 0.576 & & 0.636 & & 0.697 & & 0.879 & & 0.939 & & 1.000 & & \\
\hline & Interval & 0 & 60 & 61 & 151 & 152 & 241 & 242 & 302 & 303 & 332 & 333 & 484 & 485 & 575 & 576 & 635 & 636 & 696 & 697 & 878 & 879 & 936 & 939 & 999 & \\
\hline E3 & Jumlah & 3 & & 4 & & 3 & & 4 & & 4 & & 4 & & 4 & & 3 & & 4 & & 4 & & 5 & & 4 & & 46 \\
\hline & Probabilites & 0.065 & & 0.087 & & 0.065 & & 0.087 & & 0.087 & & 0.087 & & 0.087 & & 0.065 & & 0.087 & & 0.087 & & \begin{tabular}{|l|l|}
0.109 \\
\end{tabular} & & 0.087 & & 1.000 \\
\hline & Kumulatif & 0.065 & & 0.152 & & 0.217 & & 0.304 & & 0.391 & & 0.478 & & 0.565 & & 0.630 & & 0.717 & & 0.804 & & \begin{tabular}{|l|l|}
0.913 \\
\end{tabular} & & 1.000 & & \\
\hline & Interval & 0 & 64 & 65 & 151 & 152 & 216 & 217 & 303 & 304 & 390 & 391 & 477 & 478 & 564 & 565 & 629 & 630 & 716 & 717 & 803 & 804 & 912 & 913 & 999 & \\
\hline
\end{tabular}

Gambar 3: Interval Variabel Tahun 2017

4. Membentuk Bilangan Acak (Generating Random Numbers)

Langkah selanjutnya adalah membentuk bilangan acak yaitu dengan rumus :

$Z_{i}=\left(a Z_{i-1}+c\right) \bmod m$.

Diketahui : $\mathrm{a}=18, \mathrm{c}=28, \mathrm{~m}=99$, dan $\mathrm{Z}_{\mathrm{o}}=22$

Tabel 7 : Bentuk Pembangkit Angka Acak(Generating Random Numbers)

\begin{tabular}{|c|c|c|c|}
\hline $\mathbf{i}$ & $(\mathbf{a . Z i}+\mathbf{c})$ & $\mathbf{Z} \mathbf{i}+\mathbf{1}=(\mathbf{a . Z i}+\mathbf{c}) \mathbf{m o d} \mathbf{~ m}$ & Interval 3 Digit \\
\hline 0 & 424 & 28 & 280 \\
\hline 1 & 532 & 37 & 370 \\
\hline 2 & 694 & 1 & 10 \\
\hline 3 & 46 & 46 & 460 \\
\hline 4 & 856 & 64 & 640 \\
\hline 5 & 1180 & 91 & 910 \\
\hline 6 & 1666 & 82 & 820 \\
\hline 7 & 1504 & 19 & 190 \\
\hline 8 & 370 & 73 & 730 \\
\hline 9 & 1342 & 55 & 550 \\
\hline 10 & 1018 & 28 & 280 \\
\hline 11 & 532 & 37 & 370 \\
\hline
\end{tabular}

Jadi angka acak yang akan digunakan dalam perhitungan simulasi rangkaian percobaan yaitu diangka 280, 370, 10, 460, 640, 910, 820, 190, 730, 550, 280 dan 370. 
5. Membuat Simulasi Dari Rangkaian Percobaan

Tahap terakhir membuat simulasi dari sebuah rangkaian percobaan dengan menggunakan bilangan acak dengan mengambil bilangan acak yang telah ditentukan (Generating random numbers) berdasarkan Interval dan jumlah penjualan yang sebelumnya telah diproses dan hitung distribusi probabilitas dan distribusi kumulatifnya. Rangkaian simulasi percobaan perhitungan manual untuk penjualan tahun 2018 dapat dilihat pada Tabel 10.

Tabel 8 : Simulasi Rangkaian Percobaan Jumlah Penjualan Tahun 2018

\begin{tabular}{|c|c|c|c|c|c|c|c|c|c|c|c|c|c|}
\hline BULAN & $\mathbf{1}$ & $\mathbf{2}$ & $\mathbf{3}$ & $\mathbf{4}$ & $\mathbf{5}$ & $\mathbf{6}$ & $\mathbf{7}$ & $\mathbf{8}$ & $\mathbf{9}$ & $\mathbf{1 0}$ & $\mathbf{1 1}$ & $\mathbf{1 2}$ & TOTAL \\
\hline $\begin{array}{c}\text { Angka } \\
\text { Acak }\end{array}$ & $\mathbf{2 8 0}$ & $\mathbf{3 7 0}$ & $\mathbf{1 0}$ & $\mathbf{4 6 0}$ & $\mathbf{6 4 0}$ & $\mathbf{9 1 0}$ & $\mathbf{8 2 0}$ & $\mathbf{1 9 0}$ & $\mathbf{7 3 0}$ & $\mathbf{5 5 0}$ & $\mathbf{2 8 0}$ & $\mathbf{3 7 0}$ & $\begin{array}{c}\text { Angka } \\
\text { Acak }\end{array}$ \\
\hline $\mathrm{E} 1$ & 2 & 4 & 3 & 6 & 2 & 3 & 4 & 6 & 2 & 6 & 2 & 4 & 44 \\
\hline $\mathrm{E} 2$ & 4 & 1 & 4 & 7 & 2 & 8 & 8 & 5 & 4 & 3 & 4 & 1 & 51 \\
\hline $\mathrm{E} 3$ & 8 & 2 & 8 & 4 & 2 & 6 & 6 & 8 & 4 & 7 & 8 & 2 & 65 \\
\hline \multicolumn{10}{|c|}{ TOTAL JUMLAH PENJUALAN } \\
\hline
\end{tabular}

Rangkaian percobaan hasil simulasi menggunakan perangkat lunak Matlab 2014a dapat dilihat pada Gambar 4, Gambar 5, dan Gambar 6.

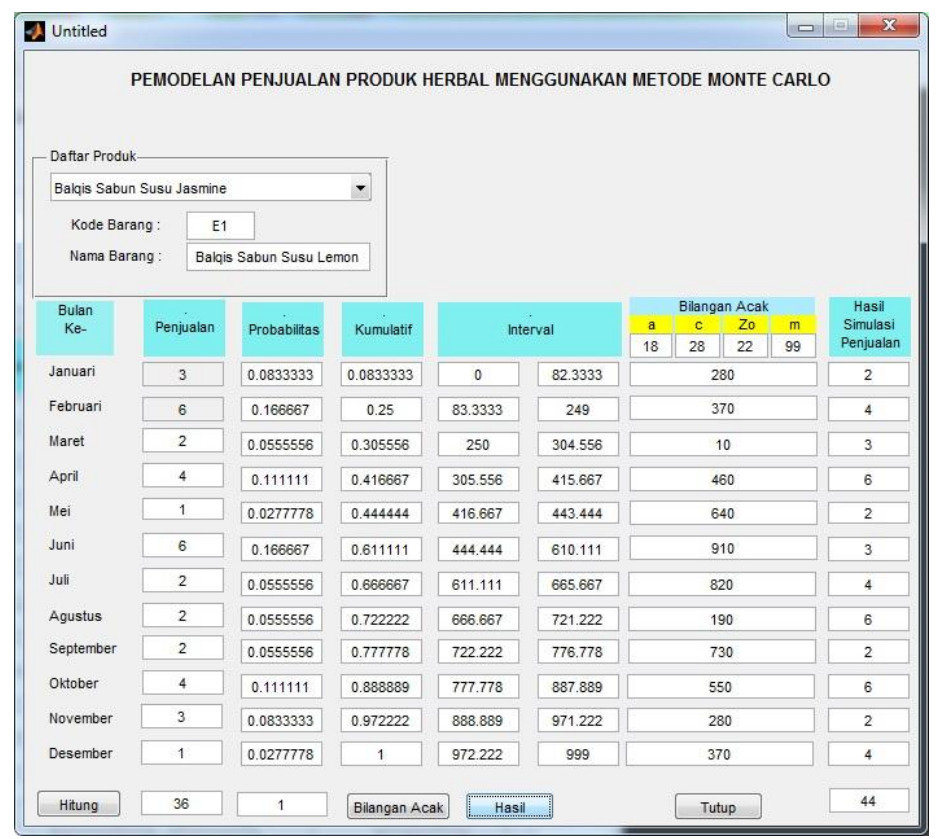

Gambar 4 : Tampilan Halaman Simulasi E1

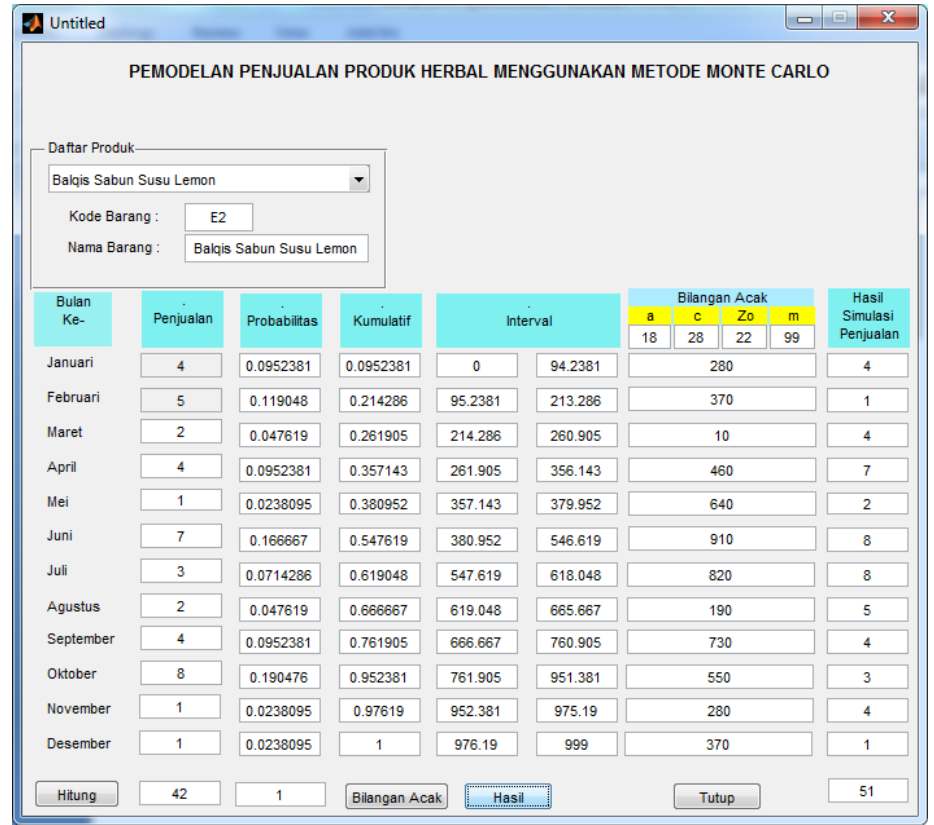


Gambar 5 : Tampilan Halaman Simulasi E2

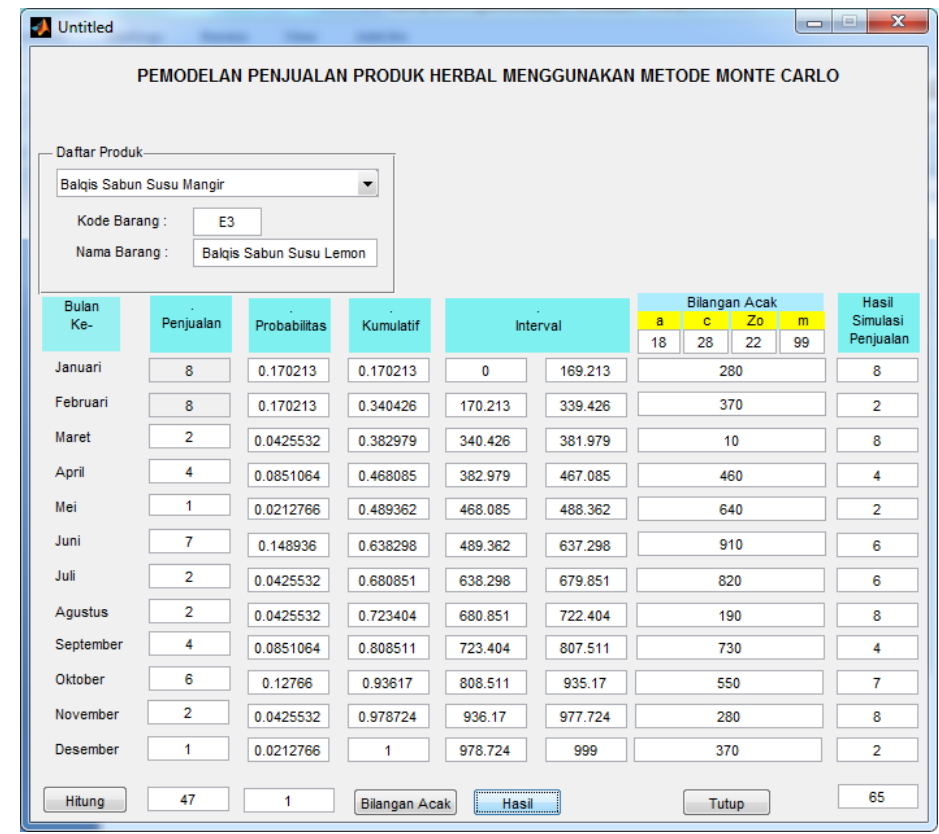

Gambar 6 : Tampilan Halaman Simulasi E3

Berdasarkan pengujian dari simulasi rangkaian percobaan, perhitungan manual dan menggunakan sistem hasilnya sama yaitu E1 sebanyak 44, E2 sebanyak 51 dan E3 sebanyak 65.

\subsection{Persentase Akurasi}

Hasil penelitian ini terhadap pengolahan data tahun 2016 hingga tahun 2017 dapat dihitung persentasenya dengan membandingakan data penjualan tahun 2017 pada Tabel 2 dengan hasil simulasi tahun 2017 pada Tabel 9.

Tabel 9 : Hasil Simulasi Penjualan Tahun 2017

\begin{tabular}{|c|c|c|c|c|c|c|c|c|c|c|c|c|c|}
\hline BULAN & $\mathbf{1}$ & $\mathbf{2}$ & $\mathbf{3}$ & $\mathbf{4}$ & $\mathbf{5}$ & $\mathbf{6}$ & $\mathbf{7}$ & $\mathbf{8}$ & $\mathbf{9}$ & $\mathbf{1 0}$ & $\mathbf{1 1}$ & $\mathbf{1 2}$ & TOTAL \\
\hline $\begin{array}{c}\text { Angka } \\
\text { Acak }\end{array}$ & $\mathbf{2 8 0}$ & $\mathbf{3 7 0}$ & $\mathbf{1 0}$ & $\mathbf{4 6 0}$ & $\mathbf{6 4 0}$ & $\mathbf{9 1 0}$ & $\mathbf{8 2 0}$ & $\mathbf{1 9 0}$ & $\mathbf{7 3 0}$ & $\mathbf{5 5 0}$ & $\mathbf{2 8 0}$ & $\mathbf{3 7 0}$ & $\begin{array}{c}\text { Angka } \\
\text { Acak }\end{array}$ \\
\hline $\mathrm{E} 1$ & 4 & 4 & 3 & 3 & 3 & 1 & 3 & 3 & 2 & 3 & 4 & 4 & 37 \\
\hline $\mathrm{E} 2$ & 4 & 2 & 3 & 2 & 3 & 3 & 3 & 2 & 3 & 3 & 4 & 2 & 34 \\
\hline E3 & 5 & 3 & 5 & 3 & 4 & 4 & 4 & 5 & 3 & 3 & 5 & 3 & 47 \\
\hline \multicolumn{10}{|c|}{ TOTAL JUMLAH PENJUALAN } \\
\hline
\end{tabular}

Hasil perbandingan data penjualan tahun 2017 dengan hasil simulasi tahun 2017 maka dapat diketahui rata-rata persentase akurasinya seperti dilihat pada Tabel 10. 
Tabel 10 : Persentasi Keakuratan

\begin{tabular}{|c|c|c|c|c|}
\hline No & NAMA PRODUK & $\begin{array}{c}\text { Jumlah Penjualan } \\
\text { Hasil Simulasi 2017 }\end{array}$ & $\begin{array}{c}\text { Jumlah } \\
\text { Penjualan 2017 }\end{array}$ & $\begin{array}{c}\text { AKURASI } \\
\text { \% }\end{array}$ \\
\hline E1 & Balqis Sabun Susu Jasmine & 37 & 35 & 95 \\
\hline E2 & Balqis Sabun Susu Lemon & 34 & 33 & 97 \\
\hline E3 & Balqis Sabun Susu Mangir & 47 & 46 & 98 \\
\hline \multicolumn{2}{r|}{ Total } & 118 & 114 & 97 \\
\hline
\end{tabular}

Jadi hasil persentasi keakuratan yang didapat pada rangkaian percobaan adalah sebesar $97 \%$. Sehingga penelitian ini sangat tepat dalam memprediksi penjualan untuk masa yang akan datang.

\section{Kesimpulan}

Hasil uji coba menggunakan metode Monte Carlo dalam Simulasi penjualan produk herbal menggunakan perangkat lunak Matlab 2104a memperoleh keakuratan sebesar $97 \%$. Prediksi keakuratan yang cukup tinggi pada penjualan produk herbal menggunakan metode Monte Carlo dapat membantu menejemen perusahaan dalam menentukan persediaan barang berdasarkan permintaan pasar pada tahun berikutnya. Diharapkan simulasi yang diaplikasikan dapat dikembangkan berdasarkan perkembangan teknologi dan informasi yang dibutuhkan.

\section{Referensi}

[1] Khairun Nizar Nasution, "Akuisisi Prediksi Penjualan Barang pada Koperasi PT. Perkebunan Silindak Dengan Menggunakan Metode Monte Carlo," Jurnal Riset Komputer (JURIKOM), Volume. 3, No 6, Desember 2016.

[2] Erwin Prasetyowati, “Aplikasi Simulasi Persediaan Teri Crispy Prisma Menggunakan Metode Monte Carlo," Jurnal Sistem dan Teknologi Informasi Indonesia (JUSTINDO), Volume 01, Nomor 01, Februari 2016.

[3] Harvei Desmon Hutahaean, "Analisa Simulasi Monte Carlo Untuk Memprediksi Tingkat Kehadiran Mahasiswa Dalam Perkuliahan,” Jurnal of Informatic Pelita Nusantara, Volume 3, No. 1, Maret 2018.

[4] Tessy Octavia Mukhti, Dodi Devianto dan Hazmira Yozza, "Simulasi Quasi Monte Carlo Menggunakan Bariasan Quasi Acak Halton;” Jurnal Matematika UNAND, Vol. VII No. 2 Hal. 221-228.

[5] Siti Hizanah Harahap, dan Nurjayadi, "Simulasi Monte Carlo dan Animasi Operasinya dalam Mengelola Persediaan Bahan Baku Bangunan," Sains dan Teknologi Informasi, Vol. 2, No. 2, Desember 2016.

[6] Gerd Wagner, "Introduction to Simulation Using Java Script," Proceeding of the 2016 Winter Simulation Conference..

[7] Ricky Zulfiandry, "Optimasi Kegiatan Pelatihan Menggunakan Metode Simulasi Monte Carlo," Jurnal Ilmiah, Volume 10 Nomor 1 April 2018.

[8] Luh Hena Terecia Wismawan Putri, Komang Dharmawan, dan I Wayan Sumarjaya, "Penentuan Harga Jual Opsi Barrier Tipe Eropa dengan Metode Antithetic Variate Pada Simulasi Monte Carlo,” E-Jurnal Matematika, Vol. 7 (2), Mei 2018, pp. 71-78.

[9] Mira Chandra Kirana dan Deni, "Simulasi Pengendalian Bahan Baku Produksi Menggunakan Metode Monte Carlo dan Exponensial," Volume 7 No. 1, Mei 2017.

[10] Mikulas Gangur and Miland Svoboda, "Simulation of Bayes' rule by means of Monte Carlo method," 2018 Teaching Statics Trust.

[11] Iphov Kumala, I Wayan Sukania, dan Santo Christianto, "Optimasi Persediaan Spare Part Untuk Meningkatkan Total Penjualan Dengan Menggunakan Simulasi Monte Carlo”, Jurnal Ilmiah Teknik Industri (2016), Vol. 4 No. 3, 166 - 174.

[12] M. Haviz Irfani, Dafid, "Estimasi Pengunjung Menggunakan Simulasi Momte Carlo Pada Warung Internet XYZ,' Jurnal Ilmiah Informatika Global, Volume 8 No. 2 Desember 2017. 